\title{
The Importance of Families in Nursing Care: Nurses' Attitudes in the Hospital Environment
}

\author{
A Importância das Famílias nos Cuidados de Enfermagem: Atitudes dos Enfermeiros em \\ Meio hospitalar \\ La Importancia de Las Familias en el Cuidado de Enfermería - Enfermeras Actitudes en el \\ Hospital
}

Carla Sílvia Fernandes*; José Augusto Pereira Gomes**; Maria Manuela Martins***; Barbara Pereira Gomes****; Lucia Hisako Takase Gonçalves*****

\begin{abstract}
Theoretical framework: Nurses' attitudes towards families are essential to the quality of nursing care, facilitating the health/ disease transition processes experienced by the family in the hospital.

Objectives: The aim of this study is to identify the attitudes of nurses in different hospital settings about the importance of including the family in nursing care.

Methodology: A quantitative, exploratory and descriptive study was conducted with a convenience sample of 160 nurses from different units in a hospital. This study used a questionnaire, which included a sociodemographic evaluation and the scale Families' Importance in Nursing Care - Nurses Attitudes (FINC-NA).

Results: The results obtained by applying the FINC-NA scale revealed high mean scores. However, the results showed no significant correlations to justify the influence of the analysed variables.

Conclusion: Nurses show a high level of agreement about the importance of families in nursing care within the various contexts of care.
\end{abstract}

Keywords: Family nursing; attitude of health personnel; hospital care

\section{Resumo}

Enquadramento: A atitude dos enfermeiros para com as famílias é determinante para a qualidade dos cuidados de enfermagem, facilitando os processos de transição saúde/doença vivenciadas pela família no hospital.

Objetivos: O objetivo deste estudo consiste em identificar a atitude dos enfermeiros de diferentes contextos de cuidados hospitalares sobre a importância de incluir a família nos cuidados de Enfermagem. Metodologia: É um estudo de natureza quantitativa, exploratório e descritivo, integrando 160 enfermeiros de diversos contextos de um hospital, através de uma amostra por conveniência. Este estudo recorre à utilização de um questionário, integrando uma avaliação sociodemográfica e a aplicação da escala A importância das famílias nos cuidados de Enfermagem - IFCE-AE.

Resultados: Os resultados obtidos da aplicação da escala IFCEAE revelam scores médios elevados. Contudo, os resultados não evidenciam correlações significativas que justifiquem a influência das variáveis exploradas.

Conclusão: Os enfermeiros possuem um grau de concordância elevado sobre a importância das famílias nos cuidados de enfermagem, no que se refere aos diferentes contextos de cuidados.

Palavras-chave: Enfermagem familiar; atitude do pessoal de saúde; assistência hospitalar

\footnotetext{
Ph.D., Adjunct Professor, Escola Superior de Enfermagem de Santa Maria, 4049-024, Porto, Portugal [carlasilviaf@gmail.com]. Contribution to the article: Search.

Address for correspondence: Rua do Valo Maior n ${ }^{\circ} 142,4049-02$, Porto, Portugal

${ }^{* * * *}$ MSc., Specialist Nurse, Hospital Centre Póvoa de Varzim/Vila do Conde, 4490-421, Póvoa do Varzim, Portugal [japgomes@gmail.com]. Contribution to the article: Statistical analysis. Varzim, Portugal [japgomes@gmail.com]. Contribution to the article: Statistical analysis.
*** Ph.D., Coordinating Professor, Porto Nursing College, 4200-072, Porto [mmartins@esenf.pt]. Contribution to the article: Guidance.

**** Ph.D., Coordinating Professor, Porto Nursing College, 4200-072, Porto, Portugal [bgomes@ esenf.pt]. Contribution to the article: Co-guidance.

***** Ph.D., Professor, Federal University of Pará, 68746-360, Castanhal - PA, Brazil [lhtakase@ gmail.com]. Contribution to the article: Treatment and statistical evaluation.
}

\section{Resumen}

Antecedentes: La actitud del personal de enfermería a las familias es fundamental para la calidad de la atención de enfermería, lo que facilita el proceso de transición de la salud / enfermedad que sufre la familia en el hospital.

Objetivos: El objetivo de este estudio es identificar la actitud de las enfermeras en los diferentes centros de atención hospitalaria en la importancia de incluir a la familia en los cuidados de enfermería. Metodología: Es un estudio exploratorio de cuantitativo y descriptivo, la integración de 160 enfermeras de diversos orígenes en el hospital, que participó libremente en el estudio, con una muestra de conveniencia. Este estudio hace uso de un cuestionario administrado directamente a los encuestados, la integración de un sociodemográfica y aplicación gama La importancia de las familias en la atención de enfermería IFCE-AE.

Resultados: Los resultados de la recopilación de datos IFCE-AE, con puntuaciones medias altas, muestran una actitud positiva hacia las familias, incluyendo ver a la familia como un interlocutor y recursos de afrontamiento. El servicio de Obstetricia obtuvo los puntajes más altos en comparación con los servicios de emergencia. Sin embargo, los resultados no mostraron correlaciones significativas para justificar la influencia de las variables recogidas, incluyendo edad, sexo, grado académico, la cualificación profesional, tiempo de servicio, la educación sobre la familia, el contexto de la atención y la experiencia con familiar enfermo.

Conclusión: Las enfermeras tienen un alto grado de acuerdo en la importancia de las familias en la atención de enfermería, en relación a los diferentes contextos importa. Sin embargo, debe ser alentado a seguir investigando sobre este tema, para entender cómo construir una práctica de cuidado de la familia y cuáles son los factores determinantes para su desarrollo.

Palabras clave: Enfermería de la familia; actitud del personal de salud; atención hospitalaria

Received for publication: 24.03 .15

Accepted for publication: 06.11 .15 


\section{Introduction}

The hospitals' welcoming attitude towards the families has evolved in recent years. In the past decades, we have seen an increased concern with humanising healthcare and facilitating the access of family members to hospital care (Dibai \& Cade, 2009). Despite this evolution, the theoretical development and the openness of hospitals to families, nursing care remain focused on the individual, based on a biomedical model, rather than on the family as client (Martins et al., 2010; Oliveira et al., 2011). In practice, the nurses still focus on individual care, which does not mean that they do not take the family into consideration, but they only consider one family member: The informal caregiver (Saveman, Mahlen, \& Benzein, 2005).

The analysis of family-focused nursing interventions is very variable in the nursing practice (Sigurdardottir, Svavarsdottir, \& Juliusdottir, 2015). Although data from existing studies show a favourable attitude towards the importance of the family in nursing care, this is not consistent with the interventions being developed (Fisher et al., 2008; Benzein, Johnsson, Arestedt, \& Saveman, 2008; Fernandes, \& Martins, 2015), which reveals a dichotomy between the models exposed and the models implemented. The nursing interventions with families in the hospital environment are limited, mainly in complex care units with patients in critical condition (Benzein et al., 2008; Wright \& Leahey, 2009; Fernandes \& Martins, 2015). Monteiro (2010), in a study on the family in hospital settings, considered the approach to the family as client as something utopian in the analysed context, due the limited intervention of nurses within the families. The family-focused nursing interventions in the hospital context operate mainly as a resource for dehospitalisation (Fernandes \& Martins, 2015).

However, it is essential to focus nursing care in the family, in a partnership of care, forcing some changes in nurses' attitudes (Monteiro, 2010). This is because "the attitudes of nurses in situations of therapeutic interaction with families translate their understanding concerning the importance of integrating their attitudes into care processes, generating practices more or less conducive to the functional empowerment of families" (Oliveira et al., 2011, p. 1330).
In this context, this study aimed at identifying the attitudes of nurses in different hospital contexts about the importance of including the family in nursing care.

\section{Background}

Hospitals have undergone many changes, particularly in terms of structure, function and operation. The hospital has been gradually considered as a company in a process of increasing rationalisation of practices (Bernardes, Cecilio, Nakao, \& Évora, 2007). In order to increase healthcare efficiency, remuneration systems are established based on the production volume by means of indicators, privileging outpatient services (Ekdahl, 2014).

The centralisation of health services, the efficiency and effectiveness expected from their interventions lead to an increasingly shorter hospital stay, with the family being expected to assume the role of caregiver, promoting dehospitalisation and family-managed care (Monteiro, 2009). The biomedical model continues to influence the healthcare services, being mainly, if not exclusively, focused on the individual, particularly in what concerns nurses (Segaric \& Hall, 2005).

The theoretical and practical evidence of the importance of the family on the health and well-being of its members, as well as the influence on the disease, motivates and forces nurses to consider family-centred care as an integral part of the nursing care practice (Wright \& Leahey, 2009). The change to a systemic approach to care is crucial, understanding the impact of health and disease on the family, given that, in any context of the care practice, nurses care for families. One indicator used to assess the quality of the relationship between health professionals and family members consists of assessing the attitudes towards the participation of families in care (Bell \& Wright, 2011; Benzein et al., 2008; Oliveira et al., 2011). The quality of the encounters between nurses and patients' family members is influenced by the nurses' attitudes about the importance of including families in nursing care (Benzein et al., 2008).

The word attitude, from Late Latin aptitudine, and the French attitude, means a way of acting, a manner of proceeding, or a demonstration of intention, and can be defined as a person's inner disposition, which translates into emotional reactions that are assimilated and subsequently experienced (Sousa, 2011). By 
observing the nurses' attitudes towards the family in the hospital context, we identify mostly supportive attitudes, considering families as a resource for nursing care (Benzein et al., 2008; Oliveira et al., 2011; Fernandes \& Martins, 2015).

Some studies have been developed at this level, highlighting the influence of some variables, including training, the context, the professional experience, etc. We cannot discuss the attitudes without taking into account the life experiences of each individual (Alves, 2011). The nurses' individual experiences have an impact on their attitudes towards families, and experiencing the illness of their own relatives shapes the nurse's positive attitudes towards the family (Benzein et al., 2008; Sousa, 2011).

In the study developed by Silva, Costa, and Silva (2013), in primary health care settings, the authors emphasise the influence of the nurses' training, years of professional experience and the unit where they work. Ângelo et al. (2014), in a study developed in paediatrics and maternal-infant units, highlights the variables: Professional experience, training in family nursing and work unit. On the other hand, Sousa (2011) describes that there are differences between the attitudes of rehabilitation specialists and other nurses concerning the importance of including families in care.

However, in a study conducted by Alves (2011) about the nurses' attitudes towards the families in inpatient units, the author found no influence of personal characteristics (gender, age, experience with ill family members), professional aspects (years of professional experience, professional category, training in family nursing), and the stress to which nurses were exposed in the hospital context. Given the current development framework, there is an urgent need to identify and expand the knowledge about the nurses' attitudes towards the importance of including families in care and validate the variables explaining this phenomenon.

\section{Research Questions}

Based on the issue presented here, the following questions arose: What are the attitudes of nurses from a hospital unit towards the families? Are there any differences depending on the care settings?

\section{Methodology}

This descriptive and correlational study adopted a quantitative approach, and was developed in a hospital with a capacity of 140 beds. The study population was composed of all the nurses working in this hospital unit, in a total of 217 nurses working in surgery, obstetrics, paediatrics, orthopaedics, emergency service, operating room, outpatient surgical unit and outpatient consultation.

In order to obtain more participants, the sample was composed of all the nurses who agreed to participate in the study. The final sample, obtained through a convenience sampling, was composed of 160 participants.

The data collection tool was a two-part questionnaire: The first part included a set of questions designed to collect sociodemographic and professional data; and the second part consisted of the FINC-NA scale.

The scale was originally developed in Sweden for measuring the attitudes of nurses from several contexts, particularly the hospital setting, about the importance of families in nursing care, entitled Families' Importance in Nursing Care - Nurses Attitudes (FINC-NA; Benzein et al., 2008).

The scale was translated to Portuguese, with the tile A Importância das Famílias nos Cuidados de Enfermagem - Atitudes dos Enfermeiros (IFCE-AE; Oliveira et al., 2011). The FINC-NA is a self-applied instrument, on a Likert-type scale. It has 26 items (Figure 1) with four answer options, with a total score ranging from 26 to 104 . The scale measures three dimensions: Family as a conversational partner and coping resource (12 items); family as a resource in nursing care (10 items) and family as a burden ( 4 items; Oliveira et al., 2011). The internal consistency of the FINC-NA scale was compared and assessed through the Cronbach's alpha coefficient, obtaining a score of 0.87 , which is identical to the one obtained by Oliveira et al. (2011). 


\begin{tabular}{|l|l|}
\hline 1 & It is important to know who the family members are. \\
\hline 2 & The presence of family members makes my job more difficult. \\
\hline 3 & A good relationship between family members gives me work satisfaction. \\
\hline 4 & Family members must be invited to participate actively in nursing care. \\
\hline 5 & The presence of family members is important for me as a nurse. \\
\hline 6 & In the first contact with the family, I invite them to participate in discussions about caregiving processes. \\
\hline 7 & The presence of family members gives me a feeling of security. \\
\hline 8 & I don't have time to care for families. \\
\hline 9 & Discussing caregiving processes with family members at the first contact saves time for future work. \\
\hline 10 & The presence of family members relieves my workload. \\
\hline 11 & Family members must be invited to participate actively in nursing care planning. \\
\hline 12 & I always try to know who the family members are. \\
\hline 13 & The presence of family members is important for family members themselves. \\
\hline 14 & I invite family members to discuss aftercare. \\
\hline 15 & I invite family members to participate actively in care. \\
\hline 16 & I ask family members how I can help. \\
\hline 17 & I encourage family members to use their resources so they can better deal with different situations. \\
\hline 18 & I consider family members as partners. \\
\hline 19 & I invite family members to talk about changes in the patient's health. \\
\hline 20 & My involvement with families makes me feel useful. \\
\hline 21 & I gain valuable knowledge with families that I can put into practice at work. \\
\hline 22 & It is important to devote time to families. \\
\hline 23 & The presence of family members makes me feel I am being judged. \\
\hline 24 & I invite family members to give their opinion on care planning. \\
\hline 25 & I consider myself as a resource for families, so they can better deal with the situation. \\
\hline 26 & The presence of family members makes me feel stressed. \\
\hline
\end{tabular}

Figure 1. Items of the FINC-NA scale. Adapted from Oliveira et al. (2011).

This process was authorised by the institution's board of directors, and also received a positive opinion from the Ethics Committee; the confidentiality of all data concerning the users and study participants was safeguarded. Data were processed through descriptive statistics and the analysis of variance using the Statistical Package for the Social Sciences (SPSS®), version 19.

\section{Results}

The response rate to the questionnaire was $73.7 \%$ (n $=160$ ). Regarding the participants' sociodemographic characterisation, most of them were women (86.9\%), with a mean age of 38.6 years and a standard deviation of 9.3 years.
In what concerns the professional characterisation, 96.9\% of the respondents hold a Bachelor's degree, only one nurse holds a Bacharelato (3-year degree), four nurses hold a Master's degree and none of them hold a $\mathrm{PhD}$. As for the professional category, 28\% are specialist nurses and $4 \%$ are head nurses. The mean length of professional experience is 16.2 years, with a standard deviation of 9.6 years.

In the specific context of training on family nursing, 59.4\% reported that they had received no training. On the other hand, $93.8 \%$ of the respondents reported having had previous experiences with hospitalised family members.

Table 1 describes the distribution according to the care setting, in a total of 12 different services with special emphasis on the operating room, the surgical unit, the medical unit (male), and the units of orthopaedics, obstetrics and paediatrics. 
Table 1

Distribution according to the care setting

\begin{tabular}{lcc}
\hline Work unit & $N$ & $\%$ \\
\hline Medical unit (male) & 18 & 11.3 \\
Medical unit (female) & 11 & 6.9 \\
Outpatient surgical unit & 12 & 7.5 \\
Emergency service & 12 & 7.5 \\
Paediatric emergency service & 8 & 5.0 \\
Outpatient consultation & 7 & 4.4 \\
Orthopaedics & 18 & 11.3 \\
Obstetrics & 17 & 10.6 \\
Operating room & 20 & 12.5 \\
Paediatrics & 17 & 10.6 \\
Surgical unit & 19 & 11.9 \\
Infection Control Committee & 1 & 0.6 \\
Total & 160 & 100.0 \\
\hline
\end{tabular}

The following table shows the distribution of the work methodology applied by nurses in their current settings of professional practice. As seen in Table 2 , the total care method is predominant (48.1\%), followed by the functional method (33.1\%), the responsible nurse method (17.5\%) and, finally, other methods (only 1.3\%).

Table 2

Representation of the work methodology

\begin{tabular}{lcc}
\hline Care methodology & $N$ & $\%$ \\
\hline Functional method & 53 & 33.1 \\
Total care method & 77 & 48.1 \\
Responsible nurse method & 28 & 17.5 \\
Other methods & 2 & 1.3 \\
Total & 160 & 100.0 \\
\hline
\end{tabular}

\section{Nurses' attitudes towards the families}

Aiming to obtain a global measure of the concordance degree, the total scores of the FINC-NA scale for each nurse were used. The overall results are presented first, followed by the comparison according to the nurses' care settings and the analysed variables. The scores obtained vary range from 65 (the minimum possible score of the scale is 26) and 104 (the maximum possible score; Table 3).

Table 3

Characterisation of the total score of the attitudes' scale

\begin{tabular}{|c|c|}
\hline Coefficients & Value \\
\hline Minimum & 65.0 \\
\hline Maximum & 104.0 \\
\hline Mean & 79.2 \\
\hline $1^{\text {st }}$ Quartile & 74.0 \\
\hline Median & 79.0 \\
\hline $3^{\text {rd }}$ Quartile & 83.3 \\
\hline Skewness Coefficient & 0.51 \\
\hline Standard deviation & 7.5 \\
\hline Coefficient of variation & $9.5 \%$ \\
\hline
\end{tabular}


The mean score is 79.2. A sharp drop was observed after 85 , with the scores gradually decreasing from that point, until reaching the maximum possible score of the scale (104). The concentration of scores leads to a low dispersion, which is reflected in the coefficient of variation of $9.5 \%$.

The mean scores for each dimension of the FINC-NA scale are presented in Table 4. In the subscale Family

Table 4

\section{Dimensions of the FINC-NA scale}

\begin{tabular}{lccc}
\hline Dimensions & No. of items & Mean (SD) & Midpoint of the subscale \\
\hline Family as a conversational partner and coping resource & 12 & $36.4(4.03)$ & 30 \\
Family as a resource in nursing care & 10 & $30.6(3.03)$ & 25 \\
Family as a burden & 4 & $12.2(1.76)$ & 10 \\
\hline
\end{tabular}

Note. Range of dimensions: Family as a conversational partner and coping resource $=12$ to 48 ; Family as a resource in nursing care $=$ 10 to 40; Family as a burden $=4$ to 16

Then, we analysed the total scores of the FINC-NA scale according to the different care settings. Some

of the services were grouped together in order to facilitate the interpretation of data (Table 5).

Table 5

Mean score of the attitudes per service

\begin{tabular}{lcc}
\hline Services & Mean & SD \\
\hline Obstetrics & 81.1 & 8.5 \\
Medical units & 80.3 & 6.8 \\
OR and OSU & 80.2 & 8.1 \\
Paediatrics & 79.9 & 8.3 \\
Outpatient consultation & 78 & 6.6 \\
Orthopaedics & 77.8 & 5.1 \\
Surgical unit & 73.7 & 5.5 \\
Emergency service & 71.3 & 7.7 \\
\hline
\end{tabular}

In relation to the medical units (male and female), the total score ranged from 66 to 91, with a mean score of 80.3. As for the data referring to the operating room (OR) and the outpatient surgical unit (OSU), the total score ranged from 67 to 99, with a mean score of 80.2. In the emergency and paediatric emergency services, which were analysed together, the total score ranged from 61 to 86, with a mean score of 71.3 . In the surgical unit, the total score ranged from 66 to 84, with a mean score of 73.7 , which is very close to the median of 72.5. In the orthopaedics unit, the total score ranged from 69 to 87, with a mean score of 77.8. In the paediatrics unit, the total score ranged from 65 to as a conversational partner and coping resource, the mean score was 36.4; in the subscale Family as a resource in nursing care, the mean score was 30.6; and in the subscale Family as a burden, the mean score was 12.2. Taking into account the maximum scores for each dimension, we observe that they all exceed the midpoint of the subscale.
100, with a mean score of 79.9. In the obstetrics unit, the total score ranged from 70 to 104 , with a mean score of 81.1. Finally, in the outpatient consultation service, the total score ranged from 66 to 85 , with a mean score of 76.9. The low representativeness of this latter group of nurses hampers the interpretation of the results (seven nurses).

Table 6 shows the analysis of the association between the total scores of the FINC-NA scale and the variables of age, gender, professional experience, academic degree, professional category, care setting, training in family nursing, and experience with ill family members. 
Table 6

Comparison of the mean score of the total FINC-NA scale and the variables under analysis

\begin{tabular}{|c|c|c|}
\hline Variable & Mean score & $p$-value \\
\hline Gender & & 0.418 \\
\hline Male & 77.9 & \\
\hline Female & 79.4 & \\
\hline Age group & & 0.906 \\
\hline 23 to 30 years & 79.2 & \\
\hline 31 to 40 years & 79.5 & \\
\hline 41 years or above & 79.2 & \\
\hline \multicolumn{3}{|l|}{ Academic degree } \\
\hline Bacharelato (3-year degree) & 66.0 & \\
\hline Bachelor's degree & 79.2 & \\
\hline Master's degree & 81.8 & \\
\hline Professional experience & & 0.950 \\
\hline 1 to 5 years & 79.1 & \\
\hline 6 to 10 years & 79.4 & \\
\hline More than 10 yeas & 79.2 & \\
\hline Experience at the current unit & & 0.751 \\
\hline Less than 1 year & 79.2 & \\
\hline 2 to 5 years & 79.8 & \\
\hline 6 to 10 years & 78.5 & \\
\hline More than 10 years & 79.1 & \\
\hline Professional category & & 0.250 \\
\hline Nurse & 73.9 & \\
\hline Specialist Nurse & 75.9 & \\
\hline Head nurse & 82 & \\
\hline Training in family nursing & & 0.652 \\
\hline No & 78.4 & \\
\hline Yes & 80.3 & \\
\hline Previous experience with ill family members & & 0.728 \\
\hline No & 76.9 & \\
\hline Yes & 79.4 & \\
\hline Care setting & & 0.286 \\
\hline Obstetrics & 81.1 & \\
\hline Medical units & 80.3 & \\
\hline OR and OSU & 80.2 & \\
\hline Paediatrics & 79.9 & \\
\hline Outpatient consultation & 78 & \\
\hline Orthopaedics & 77.8 & \\
\hline Surgical unit & 73.7 & \\
\hline Emergency services & 71.3 & \\
\hline Work methodology & & 0.272 \\
\hline Functional method & 78.2 & \\
\hline Total care method & 79.8 & \\
\hline Responsible nurse method & 80.3 & \\
\hline
\end{tabular}

Table 6 shows no statistically significant differences that might influence the nurses' attitudes towards the importance of families. The comparison based on the academic degree was not possible because there is only one nurse holding a Bacharelato (3-year degree), four nurses holding a Master's degree and none holding a $\mathrm{PhD}$. 


\section{Discussion}

The nurses who participated in this study reveal a favourable attitude towards the importance of including families in nursing care. These results are similar to those obtained in other national (Sousa, 2011; Alves, 2011, Oliveira et al., 2011; Silva et al., 2013) and international studies (Benzein et al., 2008; Ângelo et al., 2014). The nurses reported to care about the families; however, is this statement consistent with the practice or has there been a limited transfer from theory to practice, which may be justified by some obstacles?

In what concerns the participants' characterisation, it should be noted that $59.4 \%$ of the participants reported having no specific training in family nursing. However, all nurses should possess the knowledge and skills necessary to approach the family in any field of nursing practice, which requires an extensive body of knowledge about family dynamics, family systems theory, family assessment and intervention, and family research (Wright \& Leahey, 2009). The lack of conceptual clarity can constitute a barrier to an adequate integration of the family in nursing care (Segaric \& Hall, 2005).

Regarding the different dimensions of the FINCNA scale, the scores obtained here are similar to those obtained in other studies, as shown in Table 7. In the subscale Family as a burden, the results are higher, which is consistent with the results obtained by Ângelo et al. (2014) in paediatric and maternalinfant units. It should be noted that considering the family as a burden is an obstacle to the development of a collaborative relationship between nurses and families (Ângelo et al., 2014).

\section{Table 7}

Comparison of the mean scores of the dimensions of the FINC-NA scale with other studies

\begin{tabular}{|c|c|c|c|c|c|}
\hline & $\begin{array}{c}\text { Obtained } \\
\text { data }\end{array}$ & $\begin{array}{l}\text { Martins et al. } \\
(2010)\end{array}$ & $\begin{array}{l}\text { Alves } \\
(2011)\end{array}$ & $\begin{array}{l}\text { Sousa } \\
(2011) \\
\end{array}$ & $\begin{array}{c}\text { Ângelo et al. } \\
(2014)\end{array}$ \\
\hline Dimension: Family as a conversational partner and coping resource & 36.4 & 35.7 & 35.7 & 35.6 & 37 \\
\hline Dimension: Family as a resource in nursing care & 30.6 & 31.5 & 30.9 & 30.9 & 33 \\
\hline Dimension: Family as a burden & 12.2 & 8.1 & 8.9 & 8.2 & 12 \\
\hline
\end{tabular}

Within the analysis of the factors that could influence the nurses' attitudes towards the importance of including families, the influence of the following variables was not confirmed: Age, gender, professional experience, academic degree, professional category, care setting, training in family nursing, and experiences with ill family members. However, there are slight differences in the total mean scores, particularly among female nurses, nurses holding a Master's degree, specialist nurses, the training in family nursing, the experiences with ill family members, the responsible nurse methodology, and the care settings.

According to the authors of the original scale (Benzein et al., 2008), female nurses demonstrate, on average, more favourable attitudes towards the families than male nurses. Although the mean scores are higher in this study, the variable was not statistically significant. Nurses with higher academic qualifications (Master's degree) obtained higher, but not statistically significant, mean scores. Silva et al. (2013) obtained higher scores.
Specialist nurses and head nurses also obtained higher mean scores, without statistically significant differences. These results are consistent with the results obtained by Sousa (2011).

Although the training in family nursing is considered an important variable in other studies (Silva et al., 2013; Ângelo et al., 2014), despite its higher mean score, it did not obtain a statistically significant difference.

The functional method obtained a lower mean score than the total care method which, in turn, was lower than the responsible nurse method, although without statistical significance. As mentioned by Silva et al. (2013, p. 27), "the care methodology based on the functional method is integrated within the perspective of the biomedical model, rather than in the concept of practices oriented towards human reactions to life processes".

There are different opinions and attitudes about the role of family members in care, particularly in acute hospital settings. The contexts of care practice seem 
to be factors that affect the behaviours related to the importance of families (Fisher et al., 2008), but this was not confirmed in this study.

The analysis of the total mean scores showed that the obstetrics unit obtained the higher mean score, in opposition to the emergency services, which obtained the lowest score. The results from the outpatient consultation service should be carefully analysed, mainly because of the small number of nurses from this service in this group. The data obtained from the emergency service may be related to the complexity of this care setting. When demands are high, nurses need to prioritise certain tasks in their practice over caring for families (Benzein et al., 2008). Some studies emphasise that nurses working in the pediatric and maternal-infant units of a hospital have a more positive attitude towards the family (Benzein et al., 2008; Ângelo et al., 2014) than those professionals working in acute care settings (Benzein et al., 2008; Fisher et al., 2008).

The nurses' attitudes, the care setting, the nurses' training and the institutional policy seem to be factors that affect the behaviours related to the presence of the family (Fisher et al., 2008), although this was not confirmed in this study. The fact that nurses recognise the importance of involving the family in nursing care is a major step (Benzein et al., 2008) to considering the family as a partner, a target and a unit of care (Oliveira et al., 2011).

\section{Conclusion}

By analysing this study based on the proposed objectives, we concluded that the majority of nurses hold a positive attitude towards the families, showing a high or very high degree of agreement, as can be seen through the application of the FINC-NA scale. The fact that nurses describe a favourable attitude towards the families is a relevant indicator of the families' integration in the care process, particularly in the illness/health transition processes.

We are aware that the family-focused care practice will depend on the nurses' concept of family, and that all nurses working in the various care settings should possess the necessary knowledge and skills to assess and intervene in the family, which was not observed in this study.
In what concerns the different care settings, there are a few differences, particularly positive in the obstetrics unit, which obtained higher scores than the emergency services. The results showed no statistically significant values capable of justifying the influence of the analysed variables, namely: Age, gender, academic degree, professional category, length of professional experience, training in family nursing, care setting, work methodology, and experience with ill family members. However, further studies must be conducted in order to understand how family-focused care practices are established and which variables influence their development.

The implications of this study for the care practice are a prerequisite necessary as a situational assessment of a care setting and inherent to a process of transformation. As for the implications for research, this study points to a possible dichotomy between discourse and practice, emphasising the importance of incorporating different methods of data collection.

\section{References}

Alves, C. M. (2011). Atitudes dos enfermeiros face à família: Stress e gestão do conflito (Dissertação de mestrado). Retrieved from de http://hdl.handle.net/10216/71914

Ângelo, M., Cruz, A. S., Mekitarian, F. F., Santos, C. C., Martinho, M. J., \& Martins, M. M. (2014). Atitudes de enfermeiros em face da importância das famílias nos cuidados de enfermagem em pediatria. Revista da Escola de Enfermagem da USP, 48(n ${ }^{\circ}$ esp.), 75-81. doi: 10.1590/\$0080-623420140000600011

Bell, J. M., \& Wright, L. M. (2011). The Illness Beliefs Model: Creating practice knowledge in family system nursing for families experiencing illness. In E. K. Svavarsdottir \& H. Jonsdottir (Eds.), Family nursing in action (pp. 15-51). Reykjavik, Iceland: University of Iceland Press.

Benzein, E., Johansson, P., Arestedt, K. F., \& Saveman, B. I. (2008). Nurses' attitudes about the importance of families in nursing care: A survey of Swedish Nurses. Journal of Family Nursing, 14(2), 162-180. doi: 10.1177/1074840708317058

Bernardes, A., Cecilio, L. C., Nakao, J. R., \& Évora, Y. D. (2007). Os ruídos encontrados na construção de um modelo democrático e participativo de gestão hospitalar. Ciência e Saúde Coletiva, 12(4), 861-870. doi: 10.1590/\$141381232007000400008

Dibai, M. B., \& Cade, N. V. (2009). A experiência do acompanhante de paciente internado em instituição hospitalar. Revista Enfermagem UERJ, 17(1), 86-90.

Ekdahl, A. W. (2014). The organization of hospitals and the remuneration systems are not adapted to frail old patients 
giving them quality of care and the staff feelings of guilt and frustration. European Geriatric Medicine, 5(1), 14-18. doi: 10.1016/j.eurger.2013.10.002

Fernandes, C., Martins, M., \& Gomes, J. (2015). Informação documentada pelos enfermeiros sobre família após um jogo. In C. Moura, I. Pereira, M. J. Monteiro, P. Pires \& V. Rodrigues (Coords.) Saúde: Do desafio ao compromisso (pp. 166-177). Chaves, Portugal: Escola Superior de Enfermagem Dr. José Timóteo Montalvão Machado.

Fisher, C., Lindhorst, H., Mattews, T., Munroe, D. J., Paulin, D., \& Scott, D. (2008). Nursing staff attitudes and behaviors regarding family presence in the hospital setting. Journal of Advanced Nursing, 64(6), 615-623. doi: 10.1111/j.13652648.2008.04828.x

Martins, M. M., Martinho, M. J., Ferreira, M. R., Barbieri Figueiredo, M. C., Oliveira, P. C., Fernandes, H. I., ... Carvalho, J. C. (2010). Enfermagem de família: Atitudes dos enfermeiros face a família: Estudo comparativo nos CSP e no Hospital. In M. C. Barbieri, M. M. Martins, M. H. Figueiredo, M. J. Martinho, L. M. Andrade, P. C. Oliveira, ... J. C. Carvalho (Coords.), Redes de conbecimento em enfermagem de família (pp. 20-33). Retrieved from http://www.esenf.pt/fotos/editor2/ redes_de_conhecimento_enfernagem_de_familia.pdf

Monteiro, B. R. (2009). A desospitalização e a gestão familiar dos cuidados. In M. E. Leandro, P. N. Nossa, \& V. T. Rodrigues (Eds.), Saúde e sociedade: Os contributos (in)visíveis da família (pp. 413-436). Viseu, Portugal: Psicosoma.

Monteiro, M. C. (2010). Vivências dos cuidadores familiares em internamento bospitalar: O início da dependência
(Dissertação de mestrado). Retrieved from http:/hdl.handle. net/10216/26357

Oliveira, P. C., Fernandes, H. I., Vilar, A. I., Figueiredo, M. H., Ferreira, M. M., Martinho, M. J., ... Martins, M. M. (2011). Atitudes dos enfermeiros face à família: Validação da escala Families' Importance in Nursing Care - Nurses Attitudes. Revista da Escola de Enfermagem da USP, 45(6), 1331-1337. doi: 10.1590/S0080-62342011000600008

Saveman, B. I., Mahlen, C. D., \& Benzein, E. G. (2005). Nursing student's belief about families in nursing care. Nurse Education Today, 25(6), 480-486.

Segaric, C. A., \& Hall, W. A. (2005). The family theory-practice gap: A matter of clarity? Nursing Inquiry, 12(3), 210-218. doi: 10.1111/j.1440-1800.2005.00270.x

Sigurdardottir, A. O., Svavarsdottir, E. K., \& Juliusdottir, S. (2015). Family nursing hospital training and the outcome on job demands, control and support. Nurse Education Today, 35(7), 854-858. doi: 10.1016/j.nedt.2015.03.003

Silva, M. A., Costa, M. A., \& Silva, M. M. (2013). A família em cuidados de saúde primários: Caracterização das atitudes dos enfermeiros. Revista de Enfermagem Referência, 3(11), 19-28. doi: 10.12707/RIII13105

Sousa, E. S. (2011). A família: Atitudes do enfermeiro de reabilitação (Masters dissertation). Recuperado de http:// comum.rcaap.pt/handle/123456789/9365

Wright, l., \& Leahey, M. (2009). Enfermeiras e famílias: Um guia para avaliação e intervenção na família. São Paulo, Brasil: Roca. 